\title{
Inquiry-Based Learning in the Arts
}

\author{
Elke Bippus and Monica Gaspar
}

\subsection{Points of Contact Between Inquiry-Based Learning and Art Practices}

The foundational publications on inquiry-based learning (inter alia, Huber 2009) demonstrate that there is a clear overlap between the emancipatory objectives of the higher education didactic principle, which has been discussed since the 1970s, and educational concepts in the fine arts: Students' self-responsibility and autonomy regarding their methods and topics, practice and experience as a productive aspect or the necessity that the activity have social relevance are some of the aspects that both educational concepts have in common. The objective of engaging in a process of constantly questioning any existing statement with inquiry-based learning can also be associated with concepts that have been valid in the arts since the 1960s.

Apart from a few exceptions, however, the notion of inquiry-based learning is scarcely used, despite elements of other concepts circulating in art education. In an age in which education and research have gained media and political attention, even in the liberal arts, we are even being increasingly warned about the inflationary use of the words "research" and "new knowledge." According to the art historian, James Elkins, these terms should "be

This article is based on the results of the "Ästhetische Praktiken nach Bologna" project ("Aesthetic practices after Bologna") (2013-2016; Zurich University of the Arts, 2013), a collaboration between the Swiss Federal Institute of Technology in Zurich (ETH), the Berne University of Arts (HKB) and the Zurich University of the Arts (ZHdK). We would like to thank the SNF for its financial support and Monika Kurath, Priska Gisler, Anna Flach and Drilona Shehu for their critical comments.

E. Bippus, Prof. Dr. $(\bowtie) \cdot$ M. Gaspar, Lic.Phil.

ZHdK Zürcher Hochschule der Künste, ith Institut für Theorie, Zürich, Switzerland e-mail: elke.bippus@zhdk.ch; mgaspar@bluewin.ch 
confined to administrative documents, and kept out of serious literature" (Elkins 2006, p. 129). Elkins advocates using established terms such as "inquiry," "investigation," "project" or simply "work" to refer to the practice of research in the arts. Given the manifold problems of the term "research" in the context of what is known as "artistic research" (Badura et al. 2015), which will not be presented here, we will address the central characteristics of inquiry-based learning below, and discuss these characteristics within the context of art education.

\subsubsection{Emphasis on Autonomy}

The basis for inquiry-based learning - like that of art education - is a personal project. From this perspective, education is not measured as a learned, retrievable pool of transmitted knowledge, but rather in the individual's own "seeking and finding, problematizing and understanding, 'astonishment' and invention, investigating and communicating" (Huber 2009, p. 13, translated). Inquiry-based learning educates because students engage in scholarship themselves, and not because they learn and acquire something that is complete. According to the relevant literature, inquiry-based learning does not necessarily impart career-relevant knowledge, but instead promotes the "core competencies for the ability to work in highly qualified occupations or professions," for example "dealing with uncertainty," which is used and practiced in research, and sustained "deep learning," in which "the learner organizes, elaborates on and critically reflects on his or her own knowledge" (Huber 2009, p. 17, translated). The ambivalence of these skills, which are known as core competencies for highly qualified occupations, have been discussed since no later than the end of the 1990s. This is because they also justify the new "capitalistic spirit" and are also an expression of profound changes in the now project-based organizational form of our society, in which the boundaries between employment and lifeworld are increasingly blurred and the professional world is determined by the dynamics of change and competition. The new capitalist spirit has integrated characteristics such as "autonomy, spontaneity, rhizomorphous capacity, multitasking [...], the search for interpersonal contacts" and highlights these as guarantees for success, which are "taken directly from the repertoire of May 1968" (Boltanski and Chiapello 2007, p. 97).

\subsubsection{Scholarship as a Social Process}

The goal of inquiry-based learning is making science tangible as a social process, and this puts it squarely in the tradition of those intellectual forefathers who saw the university as an educational institution. They assumed that students become self-reliant by treating them as though they already are. While inquiry-based learning sees this self-reliance as being guaranteed by systematically running through a research cycle which makes cognitive and emotional experiences possible, a pre-structured research cycle is problematic from the perspective of the arts. Such a cycle is necessarily finalistic in the sense that it 
implies an end that occurs as soon as one communicates the knowledge or problemsolving. In the arts, on the other hand, not only can problems remain unbiased as to the result, there is in fact an implicit demand that they remain open and negotiable. At issue are the complexity of problems and the proliferation of possible reflections thereof, and "an individual solution [...] to a universal condition" (Geyer 2008, p. 62), as the artist and theoretician Andrea Geyer writes.

A second aspect of scholarship as a social practice is participation. Participation in a research cycle in the area of inquiry-based learning requires that all participants, i.e. instructors and students, be empowered: Each assumes responsibility vis-à-vis the group. In the literature, inclusion is doubly characterized as strengthening social competencies and at the same time having a disciplining effect in that a community is formed, in which there is mutual monitoring.

The focus of a collaborative research activity corresponds with developments in the arts since the 1980s that adhere to the concept of collective authorship, as in the media arts. This is distinct from the individualistic concepts of (art) learning; pointing the way are the concepts of the "dividuum" or atomized subjectivity, which question the assumption of an "undivided" and self-contained living entity, and which describe a non-individual singularity using the terms "dividuum" and "dividuality" (Raunig 2010). Artistic practice is linked to the ability to delegate artistic decisions and to recognize and contextualize the complex relationships of one's own work. In the arts, the production of knowledge is commonly understood to be a social process that can be communicated through collective discussion, exhibiting or presenting one's own work, and that is made tangible as a moment of insight.

\subsubsection{Reflexivity and Criticality of Inquiry-Based Learning}

Like art since the 1960s, the concept of inquiry-based learning is linked to the idea of institutional critique: for example, by questioning every established knowledge structure and every educational concept. Accordingly, the question of whether art is teachable is among the paradoxical and productive characteristics of teaching art. Moreover, since the 1970s, institutional criticism as an art movement - which attempts to use its critical reflections to maintain or open up new, autonomous scope for action - has led to the deterritorialization of the classroom or, concretely, to an "educational turn" in the form of open teaching concepts and experimental structures: The Bologna Process with all its discontents "is also seeing an unprecedented number of self-organized forums emerging outside institutions, as well as self-empowered departures inside institutions" (Rogoff 2008, p. 6).

As the educational theorist Münte-Goussar discusses, for example, despite critical approaches, inquiry-based learning can also be used as another optimization technique for neoliberal, market-oriented educational concepts. Inquiry-based learning promises a selfeducating and self-organizing, resilient, flexible subject that can adapt to the diverse demands of today's lifeworld. This subject promises to correspond with the connection 
between knowledge and creativity as a new central productive force and appears to have been furnished with the ability to make child's play of dealing with non-hierarchical, nonbureaucratic forms of organization. Originally it was artistic forms of employment in particular that were characterized by a project and team orientation, flexibility, a short-term nature and uncertainty, which became exemplary given these new neoliberal requirements (Von Bismarck and Koch 2005).

Values such as self-determination and self-actualization that have traditionally been associated with art are now part of the requirement profile for managers in the neoliberal working world. The use or even the appropriation of ideas and ideals that are emancipatory and related to educational policy for a neo-liberal maximization of profits makes it necessary, in our opinion, to take a closer look at inquiry-based learning and emancipatory educational practice. In so doing, we should point out those aspects that oppose the capitalist apparatus of justification - the "attractive, exciting life prospect, while supplying guarantees of security and moral reasons for people to do what they do" (Boltanski and Chiapello 2007, p. 25) - in order to reveal differences and prevent, and to prevent shortcircuiting self-education with the logic of self-optimization. This is because these days, demands of autonomy and attributions of responsibility are likewise the instrument of a new exercise of power that is conducive to the ideology of a neoliberal market.

\subsection{Art Education in Its Sociopolitical Framing}

Art education is always rooted in the context of historical, social, cultural and theoretical developments and debates. It is therefore not surprising that there are always revisions and new conceptualizations of teaching methods. These concepts appear to be committed to the fundamental objective of developing areas of freedom and opportunities with students, in which an attempt is made to develop an individual position within a state of constant selfquestioning and the artistic experiment that can hold its ground in the face of current artistic and social events. Instructors in the "free arts" emphasize explicitly that their objective is to support the individual development of an artistic personality (Gisler and Shehu 2016). Since in many ways, art always reflects social developments and phenomena, it is necessary to relate to contemporary issues which are debated in discourse and practice in order to develop a critical and at least temporarily emancipatory individual attitude and practice, and to create the necessary areas of freedom. Reflection on art education is thus accompanied by different, ever new reference points. For several decades, these have been digitality, gender, ecology, economization, postcolonialism and knowledge.

Art education and its objectives of not just preserving, but rather expanding areas of freedom under the respective current conditions, of responding critically and resisting normative requirements and of claiming relevance in society are not exactly supported by the declaration, adopted in Bologna in 1999, of a shared European higher education area. A wave of critical reactions and engagement with the Bologna reform on the part of art institutions has generated extensive literature. It should be noted that the reform promotes 
the tendency to draw a distinction between research institutions and teaching institutions and thus supports the establishment of mass and elite universities. Many of the developments triggered by the Bologna Reform are critically reflected by representatives of inquiry-based learning, as well as by artists and scholars who teach. Numerous academies in Germany and Austria have availed themselves of the opportunity to continue the "fine arts" as a study program that awards a Diplom, instead of adapting the B.A./M.A. system, using critical and even resistant strategies towards the Bologna reform.

In Switzerland, on the other hand, the Bologna reform was implemented in all departments, and the former schools of arts and crafts were "upgraded" to universities of applied sciences. Art colleges in Switzerland follow in the tradition of vocational schools of arts and crafts, which brings with it certain difficulties when integrating methods of inquirybased learning. With the exception of the Geneva School of Art and Design, according to their own self-conception, the schools of arts and crafts in no way aimed to educate fine or free artists, but instead trained them as typographers, photographers, lithographers and graphic designers. This tendency, which dates back to the 1870 s, and which was significantly marked by the Arts \& Crafts movement, reinforced that instruction was related to industrial needs and was not at all academic in nature. As a consequence, there were hardly any specialist-subject classes in Switzerland in which it would have been possible to study the fine arts until well into the second half of the twentieth century. The absence of an academic tradition was also noticeable when it came to research approaches. One exception to this was the "F+F School of Art and Media Design in Zurich": The Swiss artist Serge Stauffer developed a theory of art as research in the 1970s (Hiltbrunner and Helmhaus Zürich 2013). In contrast to the academies for the visual arts, this was characterized by the development of more comprehensive concepts of art and design and a reform-oriented pedagogy.

With the research project "Aesthetic practices after Bologna” (“Ästhetische Praktiken nach Bologna," Hochschule der Künste Bern 2019), we examined the effects of academization in the training courses for the graphic arts/fine arts, design and architecture at Swiss institutions of higher learning. Using a praxeological and cultural-critical approach, we addressed the question of how aesthetic practices are mediated, how these practices were impacted by the research imperative since Bologna, and whether it is possible to discern the formation of specific epistemic cultures for the respective departments. Various authors have stated that in Switzerland, the research assignment - which was swiftly institutionalized and bureaucratized as a "top-down" decision in the form of research institutes - was issued to the art colleges before a significant scene for artistic research existed. In the course of this development, what is considered research within the arts is that which is classified and recognized as financeable research by the funding agencies. The findings of our research project made it clear that it is not the discipline itself that determines the form and content of its research, but rather a group of mainly non-specialist actors (representatives of the established university disciplines, those in senior positions related to higher education policy, administrative personnel or interdisciplinary bodies comprised of heterogeneous institutions). 
The results of our research show that the art departments assume that they are meeting students on an equal footing as artists. They wish to keep education as free as possible of structural requirements. In the field of design, the metaphor "shoulder to shoulder" is frequently used in order to describe a de-hierarchized, process-oriented understanding of teaching and learning. Unlike some recent studies of German art colleges, which suggest a potential to transfer artistic research to the concept of inquiry-based learning, the studies of the "Aesthetic practices after Bologna" make it clear that the open, experimental and sometimes fuzzy understanding of research in everyday teaching differs from that of artistic research. It therefore seems necessary to grasp research in a pluralistic way so that research approaches are not reserved for master's degree programs in the form of artistic research. In consequence, a methodically rigorous and systematic conception of research should not be pitted against experimental, tentatively seeking, unconventional research that is not goal-oriented. This would reduce the complexity and heterogeneity of research approaches and knowledge forms alike.

\subsection{Research in the Arts - Alternative Educational Scenarios}

Since art colleges received an official research assignment, the question of which specific forms of knowledge and cognition are generated and transmitted through the arts and in artistic and aesthetic processes is also currently being debated, in addition to the question of what is meant by research in the arts. Artistic research, which is increasingly institutionally anchored at art colleges, is currently often perceived as the academization and narrowing of the research-experimental scope of art. As a result, representatives of a research-experimental approach distance themselves from artistic research while campaigning for aesthetic thinking or research in the arts, which is claimed to be a countermodel to scientific research. Thus, for example, the journal "MaHKUscript. Journal of Fine Art Research" was recently established as the successor to what had been "MaHKUzine. Journal of Artistic Research" (2006-11), and is undertaking a reflexive critical shift in perspective by questioning the meaning of "research" and "knowledge production" in contemporary artistic production (and specifically not in artistic research).

Finally, based on three concepts that are currently exerting a determining influence on considerations of education in art, we would like to outline alternative educational scenarios: a) unlearning, b) maintaining the "safe space" and c) inquiry-based art in the broad field of social and political action.

\subsubsection{Unlearning}

In the day-to-day work with students, it is remarkable that their ideas about art and its characteristics, possibilities and functions frequently stem from superficial and reductionist polarizations between art and science or between theory and practice. These judgments (and prejudices) are conveyed through their artistic work, which they develop and 
implement independently since, as mentioned, there are no assignments in the fine arts. In individual mentoring, in plenary or in group critiques, students practice and reflect in critical engagement with their engagement with their concerns and the depiction thereof. In this regard, no generally binding knowledge nor generally binding practice is imparted. Rather, what is required is a constant self-criticism of one's own practice, aesthetics and thinking. To this end, however, it is indispensable to reflect on the subjective practice and subjective knowledge in relation to universal or general historical as well as contemporary phenomena and developments that are of an aesthetic, ethical or political nature. To this extent, art education is always a self-exploration. When working with students who are methodically pursuing research approaches and practices, it is striking that engagement with the concepts of knowledge and knowledge production have gained increased significance, and that an attempt is being made to achieve emancipation from the Eurocentric perspective. In this context, the concept of learning is less at issue than that of unlearning. This term, which originates with postcolonial theory, is linked to a critical engagement with "how knowing occurs" as opposed to "what one knows," to use the words of Gayatri Spivak, the central thinker of postcolonialism and aesthetic education (Spivak 1990). Unlearning means reflecting on one's own privilege as a loss or in other words, to recognize that one's own privileges and the ways of thinking and worldviews that are developed therewith (can) always have a disabling effect (ibid.).

In art, the need to unlearn is manifested in the reflective statements of artists who teach. As the Austrian artist Reiner Ghanal writes in an interview for the PARSE Journal of Artistic Research, for example:

Investigating Euro-centrism and cultural arrogance, I could use myself as a good and readily available exemplar. I came to better understand myself and my biased cultural background, a process that is still ongoing, hence, I'm still unlearning. (Ganahl 2015, p. 67)

There appears to be little reflection on this aspect of unlearning in the discussion on inquiry-based learning. Thus, for example inquiry-based learning is often traced back to and founded on the Humboldtian educational ideal without taking a scientific-critical perspective (Huber 2009, p. 14). The nexus between "learning" and "unlearning" must be considered in the analysis of educational processes and of processes of autonomous knowledge production so that we can then ask why only a certain "knowledge" is requested and who is developing which educational motivations and when (Castro Varela 2008). Such reflections can be triggered in various ways, and what is urgently needed in the field of art is a practice that is in itself connected with an inherent reflection upon that practice.

\subsubsection{Maintaining the "Safe Space"}

Both inquiry-based learning and art studies cultivate protected spaces for the development of new ideas. The protected space of an academic institution can be understood as a metaphor for moments "of speculation, expansion and reflexivity" (Rogoff 2008, p. 2). The 
safe space is not a sound, autonomous world, however, but instead is comparable to a laboratory, a space in which to meet and experiment, and which is open to all sorts of uncertainties and conflicts, for a variety of positions. Given the pressure of the creative industry and the art market and their dictates of efficiency, innovation or productivity, such spaces are seriously at risk.

\subsubsection{Inquiry-Based Art "in the Expanded Field"}

In addition to safe spaces, art education also calls upon those that address the demarcations between public-social and institutional-private space. Here it is worth mentioning the use of non-commercial spaces operated by artists (alternative spaces beyond the "white cube," i.e. beyond the exhibition of art in the typical white gallery space) or project work in conflict zones. In this context, methods of transdisciplinary research between art, scholarship and society become relevant in order to tackle research itself and to answer questions such as: "How can we develop a new, democratic understanding of research? How can we initiate research processes that potentially involve all members of society, depending on the research question, the field of investigation and the nature of the problem?" (Peters 2013, p. 12, translated). In this case, this is a matter of additional participation, i.e. participation in constituting urgent questions and problems. It is therefore not about the accumulation of knowledge, but rather about questioning the logic of knowledge such as hegemonic forms of knowledge.

\subsection{Summary}

Education within the art world is described as the process-oriented work of open-ended experimentation and speculation, which is subject to unpredictability, and which requires a high degree of self-organization and self-criticism. Art is always called upon to tackle the boundaries of what has been established and to explore unexpected possibilities. From art it is expected to problematize normative social and political conditions and make alternative spaces possible - and not just for research.

\section{References}

Badura, J./Dubach, S./Haarmann, A./Mersch, D./Rey, A./Schenker, C./Toro Pérez, G. (Hrsg.). (2015). Künstlerische Forschung. Ein Handbuch. Zürich, Berlin: diaphanes.

Boltanski, L./Chiapello, E. (2007). The New Spirit of Capitalism. 1st ed. 2005. London, New York: Verso.

Castro Varela, M. d. M. (2008). Maria do Mar Castro Varela im Interview mit Vina Yun. Das Begehren neu ordnen: Autonome Wissensproduktion in postkolonialer Perspektive. Frauensolidarität, 1, $10-11$. 
Elkins, J. (2006). On Beyond Research and New Knowledge. In Elkins, J. (ed.), Artists with PhDs. On the New Doctoral Degree in Studio Art (pp. 111-133). Washington DC: New Academia Publishing.

Ganahl, R. (2015). Strange teaching. The Artist as Excellent and Miserable Teacher. PARSE Journal, Göteborg: Platform for Artistic Research Sweden, 1, 65-74. Retreived 25 April 2016 from http://www.parsejournal.com/article/strange_teaching/

Geyer,A. (2008). Notes on teaching art and feminism. In S. Schaschl-Cooper/B. Steinbrügge/R.Zechlin (Hrsg.), Cooling Out. On the Paradox of Feminism (pp. 58-66). Basel: Kunsthaus Baselland.

Gisler, P./Shehu, D. (2016). Performative Kapazität der künstlerischen Autonomie. Ethnographische Beobachtungen im Hochschulkontext. In U. Karstein/N. T. Zahner (Hrsg.), Autonomie der Kunst? Zur Aktualität eines gesellschaftlichen Leitbildes (Reihe: Kunst und Gesellschaft). Wiesbaden: Springer Verlag.

Hiltbrunner, M./Helmhaus Zürich (Hrsg.). (2013). Serge Stauffer: Kunst als Forschung. Essays, Gespräche, Übersetzungen, Studien. Zürich: Scheidegger \& Spiess.

Hochschule der Künste Bern (2019). Ästhetische Praktiken nach Bologna. Retrieved 4 March 2019 from https://www.aesthetischepraktiken.com/

Huber, L. (2009). Warum Forschendes Lernen nötig und möglich ist. In L. Huber/J. Hellmer/ F. Schneider (Hrsg.), Forschendes Lernen im Studium (pp.9-35). Bielefeld: UniversitätsverlagWebler.

Peters, Sybille (Hrsg.). (2013). Das Forschen aller - ein Vorwort. In Dies. (Hrsg.), Das Forschen aller. Artistic Research als Wissensproduktion zwischen Kunst, Wissenschaft und Gesellschaft (pp. 7-21). Bielefeld: transcript.

Raunig, G. (2010). Etwas mehr als das Commune. Dividuum und Condividualität. Grundrisse. Zeitschrift für linke Theorie und Debatte, 35. Retreived 25 April 2016 from http://www.grundrisse.net/grundrisse35/Etwas_Mehr_als_das_Commune.htm

Rogoff, I. (2008). Turning. In e-flux journal \#0 - november 2008, (p 1-10).

Spivak, G. C. (1990). Strategy, Identity, Writing. In S. Harasym (Hrsg.), The Post-Colonial Critic. New York/London: Routledge.

Von Bismarck, B./Koch, A. (Hrsg.). (2005). Beyond education. Kunst, Ausbildung, Arbeit und Ökonomie. Frankfurt am Main: Revolver.

Open Access This chapter is licensed under the terms of the Creative Commons AttributionNonCommercial-NoDerivatives 4.0 International License (http://creativecommons.org/licenses/bync-nd/4.0/), which permits any noncommercial use, sharing, distribution and reproduction in any medium or format, as long as you give appropriate credit to the original author(s) and the source, provide a link to the Creative Commons licence and indicate if you modified the licensed material. You do not have permission under this license to share adapted material derived from this chapter or parts of it.

The images or other third party material in this chapter are included in the chapter's Creative Commons licence, unless indicated otherwise in a credit line to the material. If material is not included in the chapter's Creative Commons licence and your intended use is not permitted by statutory regulation or exceeds the permitted use, you will need to obtain permission directly from the copyright holder.

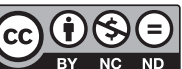

